prolactin or sex steroids, since a recent report suggested an association between constipation and benign and malignant breast disease. ${ }^{5}$ The high incidence of mastalgia and galactorrhoea-seven out of 28 women in this series-is likely to be a problem only if the drug is to be used for persistent symptoms in an essentially benign condition such as the irritable bowel syndrome. Currently, marketing of the drug in Britain is restricted to short term use in acute nausea and vomiting, such as may be associated with cytotoxic treatment. In such cases the adverse effects that we report are unlikely to be of concern.

We have informed both the Committee on the Safety of Medicines and Janssen Pharmaceuticals Ltd of our findings.

We are grateful to Janssen Pharmaceuticals Ltd for financial support to PAC and the supply of domperidone.

Prolactin concentrations were kindly measured by Dr G W Pennington, of the endocrine laboratory at the Jessop Hospital for Women, Sheffield, using an in house radioimmunoassay.

${ }^{1}$ Reyntjens AJ, Niemegeers CJE, Van Neuten JM, et al. Domperidone, a novel and safe gastrokinetic antinauseant for the treatment of dyspepsia and vomiting. Arzneim Forsch 1978;28:1194-6.

${ }^{2}$ Moriga M. A multicentre double-blind study of domperidone and metoclopramide in the symptomatic control of dyspepsia. Royal Society of Medicine International Congress and Symposium Series 1981;36:177-9.

${ }^{3}$ Cammani F, Genazzani AR, Massara F, La Rosa R, Cocchi D, Muller EE. Prolactin releasing effect of domperidone in normoprolactinaemic and hyperprolactinaemic subjects. Neuroendocrinology 1980;30:2-10.

4 Judd S, Lazarus L, Smythe G. Prolactin secretion by metoclopramide in man. $\mathcal{F}$ Clin Endocrinol Metab 1976;43:313-7.

${ }^{5}$ Petrakis NL, King EB. Cytological abnormalities in nipple aspirates of breast fluid from women with severe constipation. Lancet 1981 ;ii: 1203-5.

(Accepted 16 February 1983)

Clinical Research Unit, H Floor, Royal Hallamshire Hospital, Sheffield S10 2JF

P A CANN, MRCP, senior medical registrar

$\mathrm{N}$ W READ, MD, MRCP, honorary consultant gastroenterologist

C D HOLDSWORTH, MD, FRCP, consultant physician

Correspondence to: Dr P A Cann.

\section{Abnormal red cell morphology in venous blood of men climbing at high altitude}

Blood samples were collected at intervals during the Mount Kongur expedition ${ }^{1}$ to establish whether a period at high altitude would result in an increase in morphological abnormalities in circulating red cells. No previous observations of red cell morphology in blood samples taken during a climbing expedition to a high mountain had been made.

\section{Methods and results}

In this study samples were taken by venesection from four climbers on four separate occasions during the climb-namely, on day $2(3555 \mathrm{~m})$, day $13(4600 \mathrm{~m})$, day $29(4600 \mathrm{~m}$, after return from $6270 \mathrm{~m})$, and day $39(4600 \mathrm{~m}$, after return from $7200 \mathrm{~m}$ ). During the entire period the climbers were breathing atmospheric air (range of oxygen pressure about $13 \cdot 7-8 \cdot 6 \mathrm{kPa}$ $(103-65 \mathrm{~mm} \mathrm{Hg})$ ) without any oxygen supplementation. After each venesection a drop of blood was immediately placed in buffered glutaraldehyde fixative and gently mixed. The tubed samples were sealed and transported so that freezing was avoided. After return blood was similarly taken from four other subjects who had not been to high altitude.

Electron microscopy-Individual aliquots from each sample were gently mixed and the cells rinsed in cacodylate buffer followed by postfixation in osmium tetroxide. The fixed cells were collected on polycarbonate membrane filters and prepared for scanning electron microscopy by ethyl alcohol dehydration and critical point drying using carbon dioxide.

Categorising of cell types-Enough photographs at a final magnification of 2000 were made of representative areas of the prepared blood samples so that no fewer than 1000 red cells were available for examination. One observer only (ESW) carried out the cell examination. The work of Brecher and Bessis ${ }^{2}$ was used as a guide for classifying morphological abnormality. Cells showing no deviation from normality were graded 0 ; slight shape distortion or a single bleb was graded 1 ; cells with irregular edges or greater shape distortion (including helmet cells) or both were graded 2 ; multiple irregularities or gross shape distortion were graded 3; category 4 was reserved for late stage echinocytes.

Results-The table records the distribution of cell types observed at the four sampling times. Standard deviations indicate the variations between subjects (small for normal values, but large in response to hypoxia). Clearly a person cannot have fewer than no cells of a particular type in his circulation.

Percentage distribution of the five cell types observed at the four sampling times in four climbers. Normal distribution in four subjects who had not been to high altitude given for comparison. Results are means (SD)

\begin{tabular}{cccccc}
\hline $\begin{array}{c}\text { Day at } \\
\text { altitude } \\
\text { (see text) }\end{array}$ & \multicolumn{5}{c}{ Cell category } \\
\cline { 2 - 6 } & 0 & 1 & 2 & 3 & 4 \\
\hline 2 & $67 \cdot 5$ & $14 \cdot 1$ & $14 \cdot 7$ & $3 \cdot 1$ & $0 \cdot 6$ \\
& $(9 \cdot 2)^{* *}$ & $(2 \cdot 5)^{* * *}$ & $(5 \cdot 6)^{*}$ & $(2 \cdot 3) \mathrm{NS}$ & $(0 \cdot 5) \mathrm{NS}$ \\
13 & $54 \cdot 8$ & $17 \cdot 0$ & $22 \cdot 6$ & $5 \cdot 0)$ & $0 \cdot 7$ \\
& $(15 \cdot 9)^{*}$ & $(2 \cdot 9)^{* * *}$ & $(10 \cdot 4)^{*}$ & $(3 \cdot 9) \mathrm{NS}$ & $(0 \cdot 8) \mathrm{NS}$ \\
29 & $45 \cdot 1$ & $19 \cdot 6$ & $25 \cdot 3$ & $9 \cdot 1$ & $0 \cdot 9$ \\
39 & $(12 \cdot 8)^{* * *}$ & $(3 \cdot 3)^{* * *}$ & $(9 \cdot 2)^{* *}$ & $(6 \cdot 6) \mathrm{NS}$ & $(0 \cdot 7) \mathrm{NS}$ \\
& $24 \cdot 7$ & $16 \cdot 5$ & $44 \cdot 7$ & $12 \cdot 7$ & $1 \cdot 4$ \\
Normal & $(12 \cdot 8)^{* * *}$ & $(3 \cdot 6)^{* * *}$ & $(9 \cdot 6)^{* * *}$ & $(7 \cdot 3)^{*}$ & $(0 \cdot 8)^{*}$ \\
& $(28 \cdot 5$ & $6 \cdot 9$ & $3 \cdot 9$ & 0 & 0.6 \\
& $(2 \cdot 6)$ & $(1 \cdot 9)$ & $(1 \cdot 0)$ & $(0 \cdot 1)$ & $(0 \cdot 3)$ \\
\hline
\end{tabular}

NS $=$ Not significant

Mean at each day at high altitude compared with corresponding mean normal (two tailed $t$ test $):{ }^{*} \mathrm{p}<0.05 ;{ }^{* *} \mathrm{p}<0.02 ;{ }^{* *} \mathrm{p}<0.01$.

\section{Comment}

It is apparent that even a mild degree of hypoxia for a short period (two days) is correlated with an increase in the proportion of morphologically abnormal red cells. As longer time was spent at high altitude so there was a decrease in the proportion of morphologically normal cells.

These results raise many questions, none of which can be answered by the present study. Is the hypoxia acting on cells already in the circulation? Is the increase of abnormalities seen with time related to the length of exposure to hypoxia? In this study as time progressed so the subjects had progressed to higher altitudes. No samples were taken on return to sea level for a study of the rate of elimination of the abnormal cells.

Interestingly the abnormalities occurred in the absence of disease known to be characterised by such abnormalities and without complicating factors such as the presence of helium as a diluent for oxygen, as in saturation divers in whom similar changes have been recorded. Divers are provided with increased oxygen partial pressure, which may be a causative factor in the appearance of abnormal red cells in the circulation. ${ }^{3}$ Our study excludes this.

We thank Jardine Matheson, of Hong Kong, for underwriting the costs of the expedition and the Medical Research Council for supporting the scientific projects pursued.

${ }^{1}$ Bonington CJS. Kongur, China's elusive summit. London: Hodder and Stoughton, 1982.

2 Brecher G, Bessis M. Present status of spiculed red cells and their relationship to the discocyte-echinocyte transformation: a critical review. Blood 1972;40:333-44.

${ }^{3}$ Carlyle RF, Nichols G, Rowles PM. Abnormal red cells in blood of men subjected to simulated dives. Lancet 1979;i:1114-6.

(Accepted 14 February 1983)

Middlesex Hospital Medical School, London W1N 8AA

P M ROWLES, FIMLT, chief technician, Bland Sutton Institute of Pathology E S WILLIAMS, MD, FRCP, professor of nuclear medicine

Correspondence and requests for reprints to: Professor $\mathrm{E} S$ Williams, Department of Medical Physics and Institute of Nuclear Medicine, Middlesex Hospital Medical School, Cleveland Street, London W1P 6DB. 